\title{
Distribution of plasma cells and other cells containing immunoglobulin in the respiratory tract of normal man and class of immunoglobulin contained therein
}

\author{
C. A. SOU T A R \\ Cardiothoracic Institute, Fulham Road, London SW3 6HP
}

\begin{abstract}
Soutar, C. A. (1976). Thorax, 31, 158-166. Distribution of plasma cells and other cells containing immunoglobulin in the respiratory tract of normal man and class of immunoglobulin contained therein. The anatomical distribution of plasma cells and other cells containing immunoglobulin in the respiratory tract, and the relative proportions of the immunoglobulin classes, have been estimated on necropsy tissues from nine adult human subjects without respiratory disease, five non-smokers and four smokers, none of whom had cough or sputum. Cell counts on multiple sections stained by immunofluorescent methods for the presence of immunoglobulin were carried out on the upper trachea, main bronchus, and lower lobe bronchus.

Cells containing immunoglobulin were found mostly in the submucous glands but were also present in the lamina propria of the tracheal and bronchial epithelium. These cells were present in the greatest concentration in the main bronchus and were always present in the lobar bronchus and, in most subjects, in the upper trachea. The cells were not always present round small bronchi and bronchioles and were virtually absent from alveolar walls.

Cells containing IgA were much more numerous than those containing other immunoglobulin classes in all subjects except one, in whom IgG and IgE cells were equally numerous. Two subjects appeared to be significantly different from the rest. One nonsmoking subject had a marked deficiency of IgA cells at all sampling sites, and one smoker had a marked excess of IgA cells. In spite of these two subjects there was no significant difference between smokers and non-smokers except in the lobar bronchus where the smokers had significantly more IgA cells than the non-smokers.
\end{abstract}

Plasma cells and other cells containing immunoglobulin are plentiful in the bronchial mucous membrane. Their function is presumably related to the immunological defence of the respiratory tract and they may be the origin of much of the immunoglobulin found in bronchial secretions, in which $\operatorname{IgA}$ is known to predominate (Falk, Okinaka, and Siskind, 1972); Artenstein, Bellanti, and Buescher, 1964; Keimovitz, 1964; Remington et al., 1964; Masson, Heremans, and Prignot, 1965) and to be present in a characteristic secretory form (Tomasi et al., 1965). Cells containing IgA and IgG have been demonstrated in the lamina propria and submucous gland of bronchial wall (Martinez-Tello, Braun, and Blanc, 1968; Tourville et al., 1969) but further knowledge of their precise anatomical distribution or of the variation in proportions between immunoglobulin classes $\bigcirc$ may be important in understanding the immuno- $\rightarrow$ logical defences against microorganisms and other potentially harmful particles and provide a basis N for comparison when studying patients with ${ }^{\text {G }}$ diseases such as advanced chronic bronchitis $\tilde{O}$ where recurrent bronchial infection suggests that $\mathbb{\omega}^{N}$ these defences are inadequate.

A study of the anatomical distribution andoo immunoglobulin class of plasma cells and other $\stackrel{\odot}{\mathbb{}}$ cells containing immunoglobulin in the respiratory $\stackrel{\oplus}{?}$ tract has therefore been undertaken on necropsy material by immunofluorescent methods.

\section{SUBJECTS}

Necropsy material was obtained from nine sub- $\overline{0}$ jects known not to have had respiratory disease 
(with particular reference to cough and sputum). Medical histories were obtained from the general practitioners, who made enquiries from relatives, or from hospital notes where available. Details of age, smoking history, cause of death, and interval between death and fixation of tissue are set out in Table I.

T A B L E I

CLINICAL DETAILS OF NINE SUBJECTS WITHOUT RESPIRATORY DISEASE

\begin{tabular}{|c|c|c|c|c|c|}
\hline Subject & Sex & Age & Smoking History & Cause of Death & $\begin{array}{c}\text { Hours } \\
\text { between } \\
\text { Death } \\
\text { and } \\
\text { Fixation } \\
\text { of } \\
\text { Tissue }\end{array}$ \\
\hline 1 & $\mathbf{F}$ & 58 & Never smoked & Barbiturate & 48 \\
\hline 2 & $\mathbf{F}$ & 65 & Never smoked & Ischaemic heart & 72 \\
\hline 3 & $\mathbf{M}$ & 60 & Never smoked & Pulmonary & 24 \\
\hline 4 & $\mathbf{M}$ & 43 & $\begin{array}{l}\text { Non-smoker for } \\
10 \text { years: } \\
\text { previousiy } \\
\text { smoked } \\
30 \text { cig/day for } \\
10 \text { years }\end{array}$ & $\begin{array}{l}\text { Ischaemic heart } \\
\text { disease }\end{array}$ & 16 \\
\hline 5 & $\mathbf{M}$ & 52 & Never smoked & Pulmonary & 40 \\
\hline 6 & $\mathbf{M}$ & 38 & $\begin{array}{l}10-15 \mathrm{cig} / \mathrm{day} \\
\text { for } 20 \text { years }\end{array}$ & Head injury, & 24 \\
\hline 7 & $\mathbf{M}$ & 68 & $\begin{array}{l}40 \text { cig/day for } \\
40 \text { years but } \\
\text { pipe } 4 \text { oz/week } \\
\text { for last } 15 \text { years }\end{array}$ & $\begin{array}{l}\text { Ischaemic heart } \\
\text { disease }\end{array}$ & 48 \\
\hline 8 & $\mathbf{M}$ & 45 & $\begin{array}{l}20 \text { cig/day for } \\
25 \text { years }\end{array}$ & $\begin{array}{l}\text { Head injury, } \\
\text { instantaneous }\end{array}$ & 72 \\
\hline 9 & $\mathbf{F}$ & 26 & $\begin{array}{l}20 \mathrm{cig} / \mathrm{day} \text { for } \\
8 \text { years }\end{array}$ & $\begin{array}{l}\text { Barbiturate } \\
\text { poisoning }\end{array}$ & 48 \\
\hline
\end{tabular}

\section{METHODS}

Tissue blocks from the upper one-third of trachea, right main bronchus close to carina, right lower lobe bronchus, and peripheral lung were snap frozen and stored at $-70^{\circ} \mathrm{C}$ until required. Adjacent tissue blocks were fixed in buffered formol saline.

IMMUNOFLUORESCENT STAINS A single-layer immunofluorescent method was used to detect immunoglobulin in $5 \mu$ cryostat sections of the frozen tissues. The sections of airway included the whole circumference, and all sections were cut as serially as the method allowed. The sections were washed before staining but irrigation of sections containing cartilage during washing was kept to a minimum to avoid dislodging them. The antisera, raised in goats against human serum IgA, IgG, IgM, and IgE, were obtained from Hyland Laboratories and were conjugated with fluorescein isothiocyanate in this laboratory. Fluorescein/protein ratios lay between $1: 2$ and $1: 4$. Conjugates were absorbed with pig liver powder before use. Potency and specificity of the antisera were confirmed by immunodiffusion and immunoelectrophoresis, and further checked by staining of rat liver previously incubated with human sera containing antinuclear antibody of known immunoglobulin class (for which I am indebted to Mrs. P. Haslam). By these methods the antisera against IgG, $\operatorname{IgA}$, and $\operatorname{IgM}$ were shown to be potent and highly specific. Using a radio-labelled preparation of an antiserum to goat serum to visualize lines of precipitation produced by immunoelectrophoresis of human serum rich in IgE against the specific antisera, it was possible to show that the antiserum to human IgE was potent but did contain some weak activity against IgG. IgE cell counts may, therefore, have been increased by the inclusion of cells containing IgG. Positive results were confirmed by blocking with unconjugated antisera.

READING OF SECTIONS Near-serial sections were stained by the monospecific antisera in sequence. They were read out of order by an observer who was unaware of the antiserum applied and from which of two or three tissue blocks the sections had been taken. The cell counts were performed by scanning systematically with the aid of a parallel line graticule until the whole of the wall of the airway had been surveyed. All recognizable cells whose cytoplasm was stained by the antiserum, except epithelial cells, were counted. Total counts per circumferential section, rather than counts per unit area, were chosen to avoid possible bias induced by such factors as uneven cell distribution or tissue oedema. Counts were performed on 16 sections at each tissue site, four sections for each antiserum. For statistical study, analysis of variance was applied to square roots of the cell counts. Untransformed data are given in the text and in tables and figures.

SECTIONS OF PERIPHERAL LUNG It was possible to wash these sections more thoroughly than those containing cartilage. No formal counts were made of plasma cells in bronchioles or air space, but the appearances were noted. These sections were stained unfixed, and after fixation in acetone for 10 minutes.

FORMALIN-FIXED TISSUES Paraffin sections of formalin-fixed tissues adjacent to those examined by immunofluorescence were stained by haema- 
toxylin and eosin to examine general tissue morphology and the presence of eosinophils, and by methyl green pyronine to visualize the plasma cells.

\section{RESULTS}

The general appearances were as follows:

Cells containing immunoglobulin were present in all sections lying between the submucous gland acini and ducts (Fig. 1) and in the lamina propria of the bronchial epithelium, often applied closely to the bronchial basement membrane (Fig. 2). The cells in submucous gland were vastly in the majority. Many cells were large, rounded cells with eccentric nuclei and plentiful cytoplasm resembling mature plasma cells (Fig. 3). Others had only scanty cytoplasm and were presumably immature plasma cells or lymphocytes (Fig. 4). Cells containing $\operatorname{IgA}$ were present in larger numbers than those containing other immunoglobulin classes, and in each subject cells containing $\operatorname{IgA}$ were either almost uniformly large, mature plasma cells at all sampling sites, or were smaller immature plasma cells at all sites. Three of the five non-smokers had small IgA cells and one of the four smokers had small IgA cells, the remainder having large IgA plasma cells.

IgA was also demonstrated in the cytoplasm of the epithelial cells of the submucous glands (Fig. 5). This staining was sometimes very intense but not present in every subject. $\operatorname{IgA}$ in this site was of ten adjacent to large IgA plasma cells but not invariably: occasionally dense IgA staining on epithelial cells was adjacent to small plasma cells or even not adjacent to any recognizable cells containing immunoglobulin. $\operatorname{Ig} \mathrm{A}$ was not demonstrated in the cells of the superficial bronchial epithelium.

CELL COUNTS There was good agreement between cell counts within each group of four sections from the same tissue block and stained with the same antiserum. The variance within each of these groups was much smaller than the variance between subjects, so that the differences between subjects at all tissue sites and for all immunoglobulin classes were highly significant $(\mathrm{P}<0.001$ in all cases except for the IgM cell counts in upper trachea, where $P<0.05$ ).

IgA IgA cells were more frequent than cells containing the other immunoglobulin classes in all subjects and in all sites (Tables II to V, and Fig. 6) except in subject 6, in whom IgG and IgE cells were equally common. The mean $\operatorname{IgA}$ cell $\overrightarrow{\overrightarrow{\vec{\omega}}}$ count was highest at the main bronchus (meano 578; SD 299) and less at the lower lobe bronchus 음 (mean 376; SD 407) and upper trachea (mean 283; $\frac{\bar{c}}{\bar{\sigma}}$ SD 209) (Table II, Fig. 6). In all subjects IgA cells were present in the main and lobar bronchus, but some subjects had very few cells in the upper ${ }^{\infty}$ trachea (Fig. 7). Sections of peripheral lung. demonstrated that $\operatorname{IgA}$ cells were to be found $\overrightarrow{\vec{\omega}}$ round small bronchi and bronchioles in the lamina $\stackrel{\omega}{\omega}$ propria (5-20 cells per circumferential section) in $\vec{x}$ five subjects, but were absent in the other four. $\dot{\omega}$ This difference did not appear to be related to smoking habits. The cells were virtually absent from respiratory bronchioles and alveoli. Free $\operatorname{IgA} \mathrm{C}_{\infty}$ was not demonstrated lining the walls of respira-을 tory bronchioles or alveoli, either in washed sections or after fixation.

The IgA cell counts of two subjects lie outside two standard deviations from those of the other $\vec{\theta}$ subjects (Fig. 7). Subject 1 had much lower cell counts at all sampling sites. This subject had never smoked, and the IgA cells were of the small variety and were not demonstrated in small bronchi or bronchioles. Examination of a postmortem sample of serum from this subject showed $\operatorname{IgA} \stackrel{0}{\circ}$ to be present in normal amounts $(170 \mathrm{mg} / 100 \mathrm{ml})$. By contrast, subject 6 had strikingly high IgA cell $\vec{\circ}$ counts in the main and lower lobe bronchus and 3 strikingly low cell counts in the upper trachea. This subject, who was also unusual in having very으. high IgG and IgE cell counts (Tables III and V), was a smoker and had no history of atopy; the $\operatorname{IgA}$ 음 cells were of the large variety and they extended $\tilde{x}$ to the small bronchi and bronchioles in large $\frac{0}{3}$ numbers.

In spite of the counts from these two atypicalo subjects the counts for the non-smokers did not $₹$ differ significantly from those of the smokers in 웅 the main bronchus or trachea but in the lobar $>$ bronchus the smokers had significantly higher $\operatorname{IgA}$ 을. cell counts than the non-smokers $(\mathrm{P}<0.05)($ Fig. 8). N

$I g G, I g M$, and IgE The mean IgG, IgM, and IgE cell counts were much lower than the IgA countso (Tables III to V) (Fig. 6), although one subject hado as many IgG and IgE cells as IgA (subject 6). The distribution of these cells followed that of the $\operatorname{IgA} \stackrel{?}{+}$ cells, but they were usually present in much smaller numbers.

Neither the age of the subjects nor the interval $\stackrel{\mathbb{\infty}}{\stackrel{\infty}{\circ}}$ between death and fixation of tissues appeared to $\mathbb{Q}$ have any influence on the cell counts (Figs 90 and 10). 


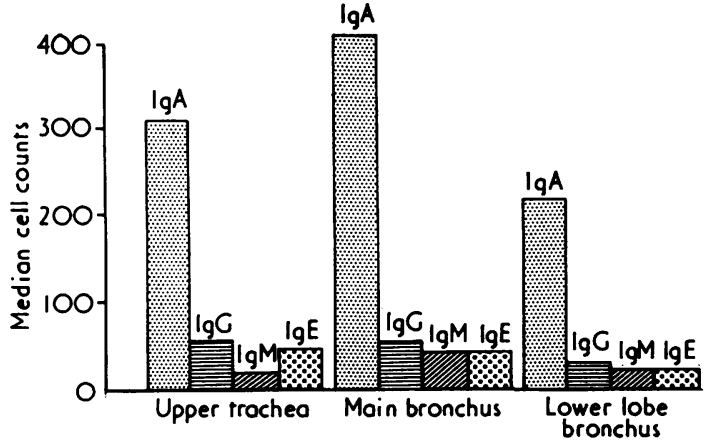

FIG. 6. Median cell counts for each immunoglobulin class in three sites in nine normal subjects.

T A B L E I I

MEAN IgA CELL COUNTS ON FIVE NORMAL NON-SMOKING SUBJECTS (1-5) AND FOUR NORMAL SMOKERS (6-9)

\begin{tabular}{c|ccc}
\hline \multirow{2}{*}{ Subject } & \multicolumn{3}{|c}{ Mean IgA Cell Counts (cells per $5 \mu$ section) } \\
\cline { 2 - 4 } & Upper Trachea & Main Bronchus & $\begin{array}{c}\text { Lower Lobe } \\
\text { Bronchus }\end{array}$ \\
\hline 1 & 70 & 122 & 70 \\
2 & 296 & 801 & 160 \\
4 & 234 & 657 & 206 \\
5 & 330 & 503 & 107 \\
\hline Grand mean & 286 & 549 & 272 \\
\hline 6 & 17 & 506 & 162 \\
\hline 7 & 134 & 1142 & 1391 \\
9 & 710 & 574 & 373 \\
\hline Grand mean & 286 & 421 & 222 \\
\hline $\begin{array}{l}\text { Significance } \\
\text { of difference }\end{array}$ & & 668 & 643 \\
between & & & \\
non-smokers & & & \\
and smokers & NS & NS & P<0.05 \\
\hline
\end{tabular}

Each figure represents the mean of four cell counts.

T A B L E I I I

MEAN IgG CELL COUNTS ON FIVE NORMAL NON-SMOKING SUBJECTS (1-5) AND FOUR NORMAL SMOKERS (6-9)

\begin{tabular}{c|ccc}
\hline \multirow{2}{*}{ Subject } & \multicolumn{3}{|c}{ Mean IgG Cell Counts (cells per $5 \mu$ section) } \\
\cline { 2 - 4 } & Upper Trachea & Main Bronchus & $\begin{array}{c}\text { Lower Lobe } \\
\text { Bronchus }\end{array}$ \\
\hline 1 & 19 & 41 & 26 \\
2 & 18 & 31 & 20 \\
4 & 66 & 115 & 28 \\
5 & 27 & 45 & 23 \\
\hline Grand mean & 61 & 39 & 24 \\
\hline 6 & 38 & 54 & 695 \\
7 & 76 & 943 & 15 \\
9 & 55 & 86 & 19 \\
\hline Grand mean & 32 & 69 & 202 \\
\hline $\begin{array}{l}\text { Significance } \\
\text { of difference } \\
\text { between } \\
\text { non-smokers }\end{array}$ & 61 & 281 & \\
and smokers & & & \\
\hline
\end{tabular}

Each figure represents the mean of four cell counts.
T A B L E I V

MEAN IgM CELL COUNTS ON FIVE NORMAL NON-SMOKING SUBJECTS (1-5) AND FOUR NORMAL SMOKERS (6-9)

\begin{tabular}{c|ccc}
\hline \multirow{2}{*}{ Subject } & \multicolumn{3}{|c}{ Mean IgM Cell Counts (cells per 5 $\mu$ section) } \\
\cline { 2 - 4 } & Upper Trachea & Main Bronchus & $\begin{array}{c}\text { Lower Lobe } \\
\text { Bronchus }\end{array}$ \\
\hline 1 & 35 & 35 & 24 \\
3 & 41 & 53 & 55 \\
4 & 23 & 38 & 13 \\
5 & 17 & 20 & 23 \\
\hline Grand mean & 19 & 36 & 17 \\
\hline 6 & 27 & 37 & 26 \\
7 & 65 & 232 & 477 \\
9 & 20 & 126 & 20 \\
\hline Grand mean & 16 & 37 & 20 \\
\hline $\begin{array}{l}\text { Significance } \\
\text { of difference } \\
\text { between } \\
\text { non-smokers } \\
\text { and smokers }\end{array}$ & 33 & 108 & 137 \\
\hline
\end{tabular}

Each figure represents the mean of four cell counts.

T A B L E V

MEAN IgE CELL COUNTS ON FIVE NORMAL NON-SMOKING SUBJECTS (1-5) AND FOUR NORMAL SMOKERS (6-9)

\begin{tabular}{c|ccc}
\hline \multirow{2}{*}{ Subject } & \multicolumn{3}{|c}{ Mean IgE Cell Counts (cells per 5 $\mu$ section) } \\
\cline { 2 - 4 } & Upper Trachea & Main Bronchus & $\begin{array}{c}\text { Lower Lobe } \\
\text { Bronchus }\end{array}$ \\
\hline 1 & 17 & 11 & 9 \\
2 & 46 & 183 & 92 \\
3 & 25 & 26 & 18 \\
5 & 24 & 16 & 14 \\
\hline Grand mean & 87 & 43 & 41 \\
\hline 6 & 40 & 56 & 35 \\
78 & 144 & 1373 & 771 \\
9 & 41 & 57 & 13 \\
\hline \begin{tabular}{l} 
Grand mean \\
\hline Significance
\end{tabular} & 65 & 31 & 21 \\
\hline $\begin{array}{l}\text { of difference } \\
\text { between }\end{array}$ & & 374 & 212 \\
non-smokers & & & \\
and smokers & NS & & NS \\
\hline
\end{tabular}

Each figure represents the mean of four cell counts.

PARAFFIN SECTIONS Examination of paraffin sections of tissues adjacent to those examined by immunofluorescent methods demonstrated normal morphology. Eosinophils were extremely scanty, so that the likelihood of non-specific staining of these cells affecting the plasma cell counts was extremely small. Plasma cells were demonstrated in numbers consistent with the cell counts on sections stained by immunofluorescent methods, although the quality of methyl green pyronin stains on these postmortem tissues was poor. 

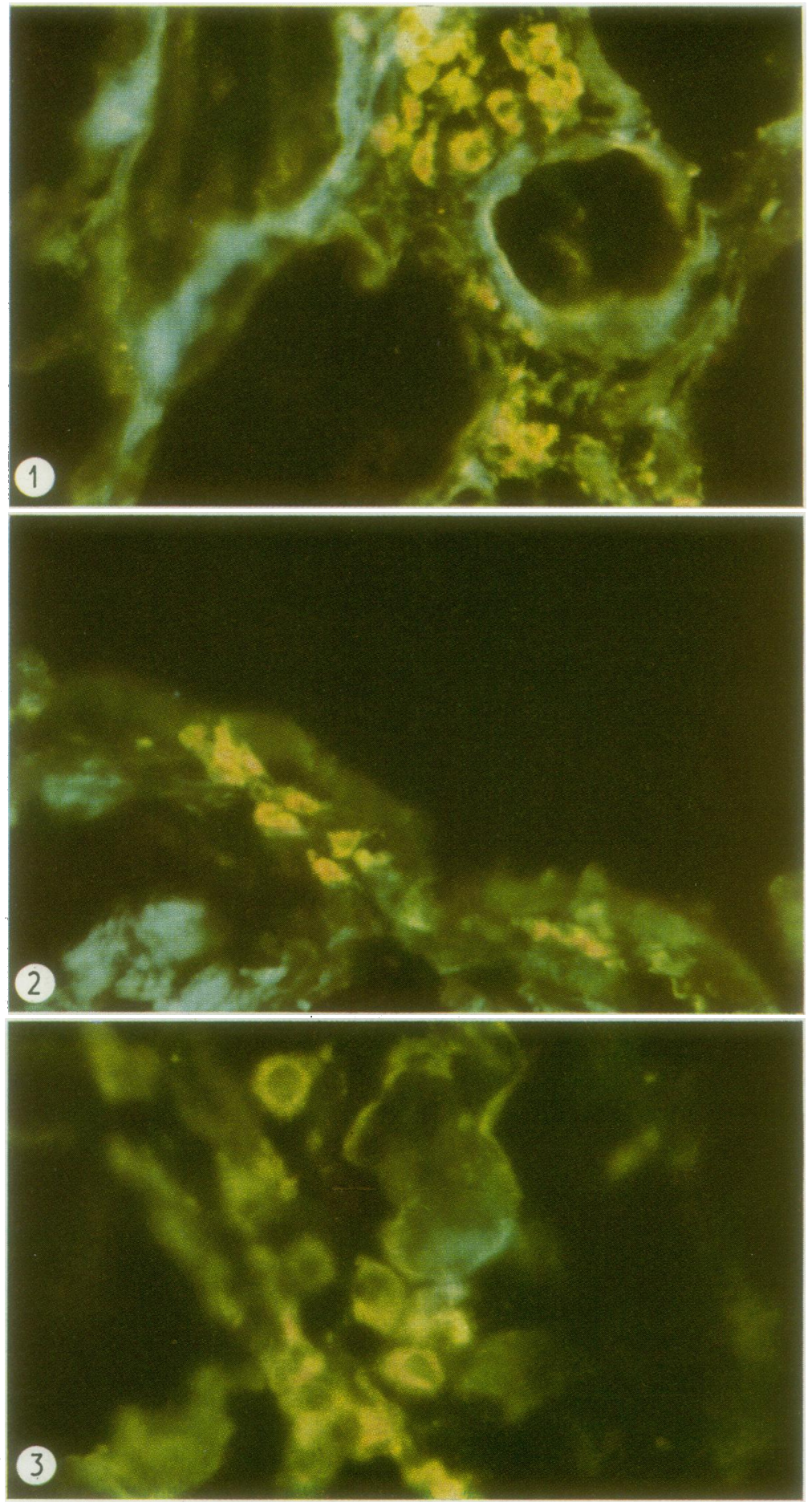

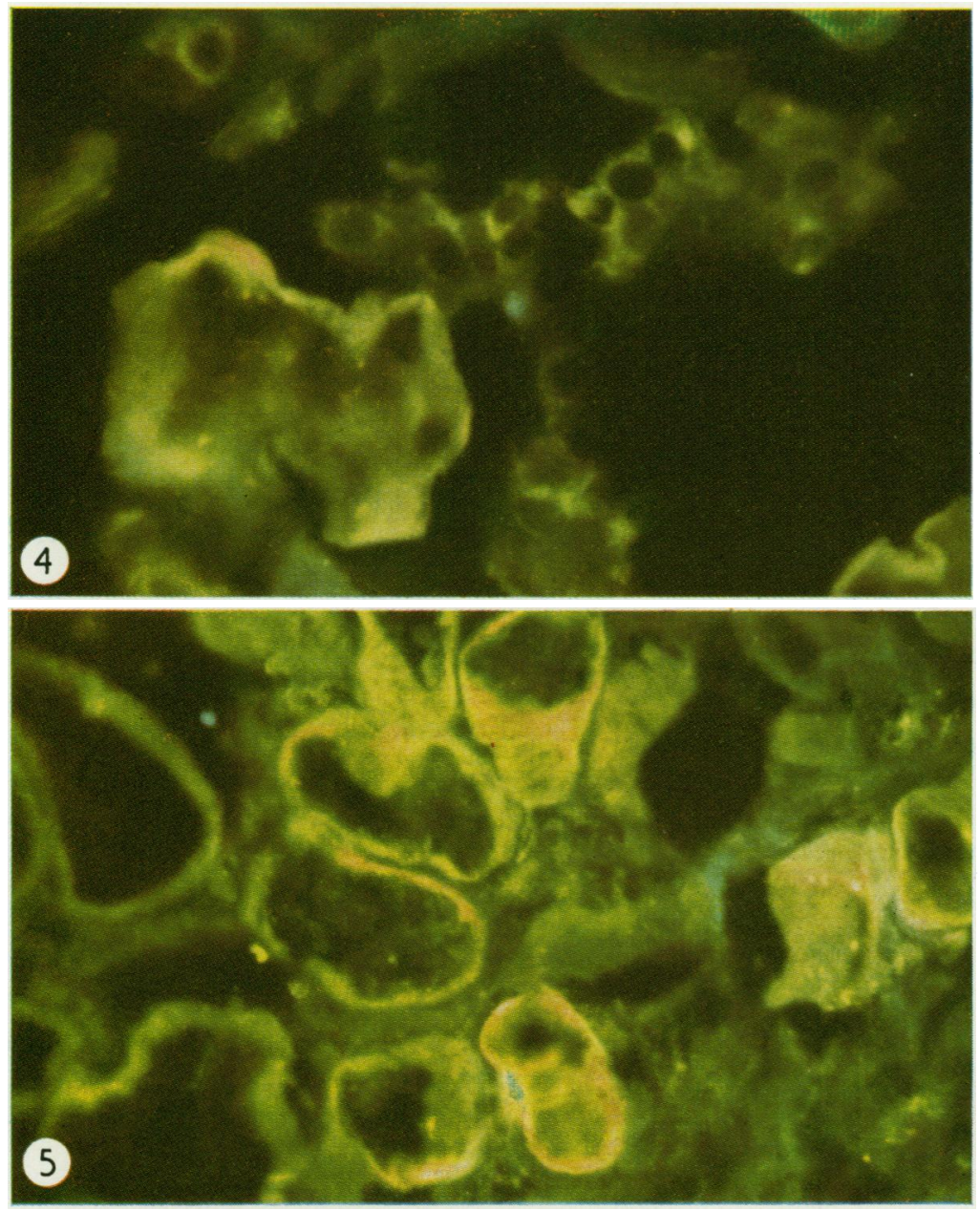

FIG. 1. Cells containing IgA lying between submucous gland acini and ducts $\times 365$.

FIG. 2. Cells containing IgA in lamina propria of bronchial epithelium $\times 365$.

FIG. 3. Mature plasma cells containing IgA in bronchial submucous gland $\times 545$. Fluorescence is also present on the epithelial cells of the submucous gland acini and ducts.

FIG. 4. Immature plasma cells containing IgA in bronchial submucous gland $\times 545$. Fluorescence is also present on the epithelial cells of the submucous gland acini and ducts.

FIG. 5. Fluorescence of epithelial cells of submucous gland (anti-IgA conjugate, $\times 365$ ). 


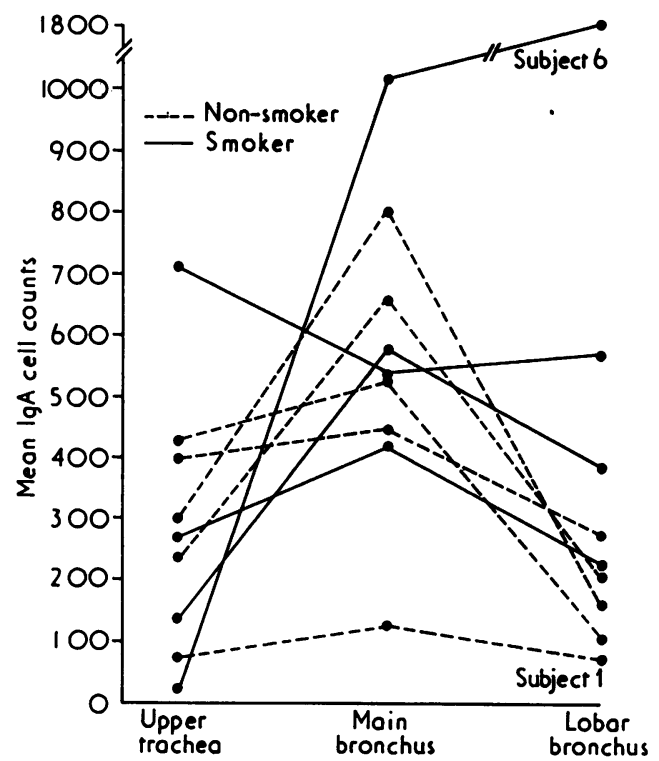

FIG. 7. Mean IgA cell counts at three sites in nine normal subjects.

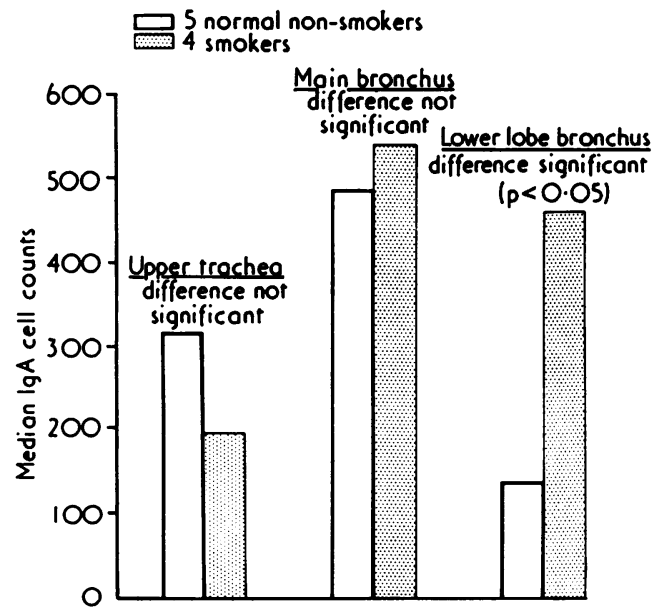

FIG. 8. Median IgA cell counts, non-smokers and smokers compared.

\section{DISCUSSION}

Presumably secretory IgA has survival value having been preserved through evolution, but its contribution towards the defence of the respiratory tract against microorganisms and other potentially harmful particles is not entirely clear. Specific virus-neutralizing activity has been identified with IgA in nasal secretions (Artenstein et al., 1964; Bellanti et al., 1964), and IgA bacterial

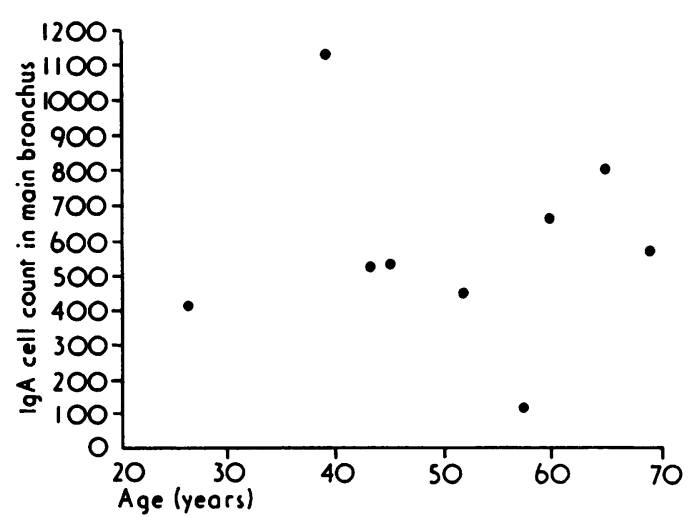

FIG. 9. Comparison between $\operatorname{lgA}$ counts in main bronchus and age of nine subjects.

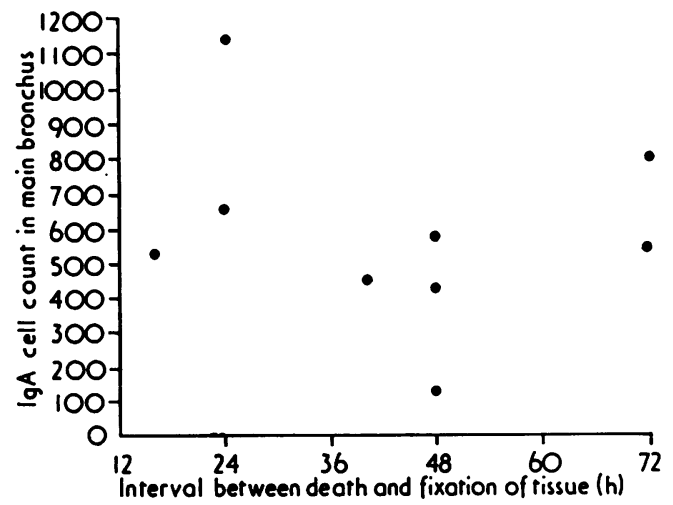

FIG. 10. Comparison between IgA cell counts in main bronchus and interval between death and fixation $\stackrel{0}{\times}$ of tissue.

antibodies have been identified in sputum (Gumpo et al., 1973; Clarke, 1975).

The presence in nasal secretions of antibody to음 parainfluenza $A$ virus has been shown to protect $>$ against subsequent infections by this organism (Smith et al., 1966). Although patients with a N serum deficiency of IgA have a high incidence of respiratory infections (Ammann and Hong, 1971), deficiency of IgA may also occur occas- $\omega$ ionally in completely healthy individuals (Rockey? et al., 1964; Bachmann, 1968).

Studies of immunoglobulins in bronchial wash-市 ings and sputum have the disadvantage that the site of origin of the immunoglobulins in the bronchial tree is ill-defined and the material may be $\frac{\text { ? }}{\mathrm{D}}$ contaminated with immunoglobulin in serum from inflamed mucosal surfaces or in saliva.

This study provides basic information on the distribution of immunoglobulins in cells in the 
respiratory tract. Cells containing IgA clearly predominate over the other immunoglobulin classes (except in one subject) in all sites examined. The number of IgG cells is somewhat less than that found by previous workers in a group, many of whom were children (Martinez-Tello, Braun, and Blanc, 1968), but is consistent with the estimate of local immunoglobulin production made by Deuschl and Johansson (1974) on studies of bronchial washings. The IgA cells are most concentrated in the main bronchus, less so in the lower lobe bronchus and upper trachea, are inconstantly present in the small bronchi and bronchioles, and are virtually absent from the gas exchange part of the lung. The cell counts in the upper trachea and the main and lobar bronchus are not always in proportion, and therefore counts at a single site are not necessarily representative of other sites in the bronchial tree.

Two subjects had cell counts at two or more sites which differed by more than two standard deviations from the rest, one with very few cells, the other with an excess. While these may merely represent the extremes of the normal variation, it is tempting to speculate that their immunoglobulin-producing cell populations were in abnormal states of activity. Healthy individuals with systemic deficiency of IgA have been reported (Rockey et al., 1964; Bachmann, 1968); but we know of no previous reports of individuals deficient in secretory IgA but with normal serum values. Whether these abnormal states were temporary or permanent, they might well have influenced the hosts' responses to infection or other environmental insult.

In this small group of subjects, the smokers had significantly higher IgA cell counts than the nonsmokers in the lower lobe bronchus but not at the other sites examined. This suggests that tobacco smoke may stimulate IgA plasma cell activity in the bronchi of subjects who have not developed chronic cough. It might be expected that this change would be more pronounced in the lobar bronchus than in more proximal sites, for studies of ventilatory function in smokers suggest that the early changes of chronic bronchitis in smokers may be more marked in the small airways (McCarthy et al., 1972; McFadden and Linden, 1972; Cochrane et al., 1974), and pathological studies suggest that the mucous gland hypertrophy of chronic bronchitis is proportionately greater in the lobar and segmental bronchi than at other sites (Restrepo and Heard, 1963).

I wish to thank Professor Margaret Turner-Warwick for a great deal of advice and encouragement and
Dr. G. Hinson and Professor R. D. Teare for much help in obtaining necropsy material. The Tobacco Research Council generously provided financial support. I also thank Miss D. Coombs and Mr. P. Townsend for technical assistance, Mrs. Annabel Gunn for secretarial help, Miss R. Pegus and the Department of Medical Art, Royal Marsden Hospital, for the illustrations, and Mr. K. Moreman and Miss A. Shapiro of the Department of Photography, Royal Marsden Hospital for the photographs.

\section{REFERENCES}

Ammann, A. J. and Hong, R. (1971). Selective IgA deficiency: presentation of 30 cases and a review of the literature. Medicine, 50, 223.

Artenstein, M. S., Bellanti, J. A., and Buescher, E. L. (1964). Identification of the antiviral substances in nasal secretions. Proceedings of the Society for Experimental Biology and Medicine, 117, 558.

Bachmann, R. (1968). Studies on the serum yAglobulin level 111. The frequency of A-yAglobulinaemia. Scandinavian Journal of Clinical and Laboratory Investigation, 17, 316.

Bellanti, J. A.. Artenstein, M. S., and Buescher, E. L. (1964). Characterization of virus neutralizing antibodies in human serum and nasal secretions. Journal of Immunology, 94, 344.

Clarke, C. W. (1975). Precipitating antibody in the sputum in chronic respiratory disease. Postgraduate Medical Journal, (in press).

Cochrane, G. M., Prieto, F., Hickey, B., Benatar, S. R., and Clark, T. J. H. (1974). Early diagnosis of airways obstruction. Thorax, 29, 389.

Deuschl, H. and Johansson, S. G. O. (1974). Immunoglobulins in tracheo-bronchial secretion with special reference to IgE. Clinical and Experimental Immunology, 16, 401.

Falk, G. A., Okinaka, A. J., and Siskind, G. W. (1972). Immunoglobulins in the bronchial washings of patients with chronic obstructive pulmonary disease. American Review of Respiratory Disease, 105, 14.

Gump, D. W., Christmas, W. A., Forsyth, B. R., Phillips, C. A., and Stouch W. H. (1973). Serum and secretory antibodies in patients with chronic bronchitis. Archives of Internal Medicine, 132, 847.

Keimovitz, R. I. (1964). Immunoglobulins in normal human tracheobronchial washings. Journal of Laboratory and Clinical Medicine, 63, 54.

McCarthy, D. S., Spencer, R., Greene, R., and MilicEmili, J. (1972). Measurement of 'closing volume' as a simple and sensitive test for early detection of small airway disease. American Journal of Medicine, 52, 747.

McFadden, E. R., Jr., and Linden, D. A. (1972). A reduction in maximum mid-expiratory flow rate: a spirographic manifestation of small airway disease. American Journal of Medicine, 52, 725.

Martinez-Tello, F. J., Braun, D. G., and Blanc, W. A. (1968). Immunoglobulin production in bronchial mucosa and bronchial lymph nodes, particularly 
in cystic fibrosis of the pancreas. Journal of Immunology, 101, 989.

Masson, P. L., Heremans, J. F., and Prignot, J. (1965). Studies on the proteins of human bronchial secretions. Biochimica et Biophysica Acta, 111, 466.

Remington, J. S., Vosti, K. L., Lietze, A., and Zimmerman, A. L. (1964). Serum proteins and antibody activity in human nasal secretions. Journal of Clinical Investigation, 43, 1613.

Restrepo, G. L. and Heard, B. E. (1963). Mucous gland enlargement in chronic bronchitis: extent of enlargement in the tracheo-bronchial tree. Thorax, 18, 334.

Rockey, J. H., Hanson, L. A., Heremans, J. F., and Kunkel, H. G. (1964). Beta-2A aglobulinaemia in two healthy men. Journal of Laboratory and Clinical Medicine, 63, 205.
Smith, C. B., Purcell, R. H., Bellanti, J. A. and $\overrightarrow{\vec{F}}$ Chanock, R. M. (1966). Protective effect of antibody to parainfluenza type 1 virus. New England Journal of Medicine, 275, 1145.

Tomasi, T. B., Jr., Tan, E. M., Solomon, A., and Prendergast, R. A. (1965). Characteristics of an immune system common to certain external o secretions. Journal of Experimental Medicine, 121, 101.

Tourville, D. R., Adler, R. H., Bienenstock, J., and Tomasi, T. B., Jr. (1969). The human secretory $\vec{\omega}$ immunoglobulin system: immunohistological localization of yA secretory 'piece' and lacto- $\overrightarrow{\vec{x}}$ ferrin in normal human tissues. Journal of Experimental Medicine, 129, 411.

Requests for reprints to: Dr. C. A. Soutar, Cardic- $\infty$ thoracic Institute, Fulham Road, London SW3 6HP. O 